\title{
STREAMFLOW AND SUSPENDED SEDIMENT LOAD TRENDS IN TROTUȘ DRAINAGE BASIN: GEOMORPHIC IMPLICATIONS
}

\section{Dan DUMITRIU ${ }^{1}$}

\footnotetext{
${ }^{1}$ Faculty of Geography and Geology, Alexandru Ioan Cuza University of Iaşi, Romania; e-mail: dndumitriu@yahoo.com; Tel.: +40 740133237
}

Key words: streamflow, suspended sediment load, trend analysis, geomorphological response, Trotuș River

\begin{abstract}
The research focusing on the trends of the streamflow and suspended sediment, as well as on the controls involved in these changes, are currently topics of significant interest in fluvial geomorphology. In this context, the aim of this study is to analyze the trends of the streamflow discharge and the sediment load based on a geomorphological approach of the relations between the two variables. These trends were assessed based on three testing methods frequently employed in hydro-geomorphological studies (Mann-Kendall trend test, Șen's slope estimator and the innovative trend method) applied on data from 10 gauging stations located on major tributaries of Trotuș River. Results reveal an overall downward trend of the mean annual streamflow and an increasing trend of the mean annual suspended sediment load. Whereas the decreasing streamflow trend was linked to the diminishing precipitation amounts, the upward trend of suspended sediment load was related to the changes occurring within river channels as a result of flood events.
\end{abstract}

\section{INTRODUCTION}

Rivers are regarded as major links between continents and oceans and play a crucial role in the manifestation of geological, geomorphic, hydrological, biological and chemical processes occurring at the surface of the crust (Milliman and Meade, 1983; Walling and Fang, 2003). In the last half century fluvial systems were severely disrupted due to anthropogenic activities (e.g. land use / land cover changes within drainage basins, river channel regularization, dam construction, gravel mining etc.) and climate changes. Anthropogenic activities are believed to have disrupted to a significant degree the spatial and temporal evolution of water resources pertaining to more than half of the major fluvial systems on Earth (Liu et al. 2005). Moreover, the global hydrological cycle was 
also affected by climate changes, primarily through the shifts occurring in precipitation and temperature regimes, which further interfere with the streamflow discharge (Vorosmarty et al. 2000). Consequently, either an increase or a decrease were documented in the streamflow and the sediment regime in close correlation with the disturbances occurring in the basin (Zhao et al. 2014). Therefore, research tackling the trends of streamflow discharge and sediment load in certain drainage basins is often addressed in hydrogeomorphological studies (Guo et al. 2018; Dey and Mishra, 2017). These studies are of great relevance both scientifically and practically especially in the fields of water resources management, flood protection and the rivers management (Barnett et al. 2005).

The studies focusing on the analysis of streamflow change trends are much more numerous compared to those addressing the shifts of the sediment load. The latter were more numerous for rivers from Asia, and China in particular. In Europe the tendencies of the streamflow are largely in line with precipitation trends, with decreasing values in southern and eastern Europe and increasing values in the north (Stahl et al. 2010, 2012). In Romania the publications pertaining to this category focused either on streamflow discharge trends in certain drainage basins (Rîmbu et al. 2002, 2004; Croitoru and Minea, 2015; Minea and Chelariu, 2020), or at national scale (Bîrsan et al. 2012, 2014, 2015; Ioniță et al. 2014; Ioniță, 2015). The trends of the suspended sediment load were studied mainly in connection with the construction of large dams. The analysis of long sediment load data series for 145 rivers across the planet revealed that in more than $50 \%$ of cases this parameter is declining (Walling and Fang, 2003). The sediment load decreased significantly in Europe in the past half century (Milliman, 2001). In Romania Rădoane et al. (2013) documented an upward trend of the sediment load in the central and northern parts of Siret drainage basin as opposed to a downward trend in the southern sector (particularly in Buzău drainage basin). Correlative studies between streamflow and sediment load trends are infrequent, as are investigations focusing on catchments, which are the fundamental units for interpreting landform dynamics (Rădoane et al. 2006). Similarly, few studies carried out in Romania looked into the factors controlling the variation of sediment loads.

This article is focused on the analysis of streamflow and sediment load trends between 1994 and 2017 at 10 gauging stations located on the main tributaries of Trotuş River.

Several approaches are available in the literature to assess the trends of hydrological variables. The most commonly used are the Mann-Kendall (MK) trend test and Șen's slope estimator (ȘSE) (Ali et al. 2019). Recently, the innovative trend analysis (ITA) or innovative trend method (ITM) introduced by 
Şen (2012, 2017) (Ali and Abubaker, 2019) is used more frequently. The study aims to analyse the trends of streamflow discharge and sediment load based on a correlative approach of the two hydrological variables. Moreover, we attempted to identify the controls responsible for the variation of the sediment load. The objectives of this study include: (i) detecting the trends and shifts occurring in the streamflow and sediment load regimes at the 10 gauging stations; (ii) identifying the potential controls which have likely led to changes in the sediment flow.

\section{DATA AND METHODS}

\subsection{Study area}

The analysis of streamflow and sediment load trends was carried out based on the data recorded at the gauging stations located on the following tributaries of river Trotuș: Valea Rece, Sulța, Ciobănuș, Asău, Uz, Dofteana, Slănic, Oituz, Caşin and Tazlău (Figure 1). The main characteristics of drainage basins upstream of the gauging stations are shown in Table 1.

Table 1. Main characteristics of the drainage basins at the gauging stations

\begin{tabular}{|c|c|c|c|c|c|c|}
\hline \multirow[t]{2}{*}{ No. } & \multirow[t]{2}{*}{ River } & \multirow[t]{2}{*}{ Gauging station } & \multirow{2}{*}{$\begin{array}{l}\text { Distance from } \\
\text { river mouth } \\
(\mathrm{km})\end{array}$} & \multicolumn{2}{|c|}{$\begin{array}{l}\text { Data regarding the } \\
\text { drainage basin }\end{array}$} & \multirow{2}{*}{$\begin{array}{l}\text { Gauging } \\
\text { station } \\
\text { elevation } \\
(\mathrm{m}) \\
\end{array}$} \\
\hline & & & & Area $\left(\mathrm{km}^{2}\right)$ & $\begin{array}{c}\text { Mean } \\
\text { elevation }(\mathrm{m})\end{array}$ & \\
\hline 1 & Valea Rece & Valea Rece & 1 & 120 & 1145 & 790 \\
\hline 2 & Sulța & Sulța & 1 & 116 & 1041 & 551 \\
\hline 3 & Ciobănuș & Ciobănuș & 1 & 135 & 1052 & 475 \\
\hline 4 & Asău & Asău & 2 & 204 & 951 & 430 \\
\hline 5 & $\mathrm{Uz}$ & Valea Uzului & 22 & 150 & 1070 & 628 \\
\hline 6 & Dofteana & Dofteana & 0.4 & 110 & 735 & 301 \\
\hline 7 & Slănic & Cireșoaia & 7 & 105 & 775 & 340 \\
\hline 8 & Oituz & Ferăstrău & 19 & 267 & 810 & 300 \\
\hline 9 & Cașin & Haloș & 18 & 220 & 717 & 298 \\
\hline 10 & Tazlău & Helegiu & 14 & 998 & 520 & 209 \\
\hline
\end{tabular}

The resistance to erosion of the geological substrate differs depending on the types of rock outcropping in these basins: thus, erosion resistant rocks are prevalent in basins such as Valea Rece, Sulța, Ciobănuș, Asău, Uz and Oituz (upper and mid basins), and Cașin (upper basin); moderately resistant rocks are dominant in Dofteana and Slănic basins; and rocks with low resistance are prevalent in basins such as Tazlău, Oituz (lower basin) and Cașin (mid and lower basins) (Dumitriu, 2014). Consequently, the most significant sediment yields were documented in basins whereby the rock resistance to erosion is low. These basins are also under the influence of strong anthropogenic intervention (Dumitriu et al. 2017). Gravel bed channels are typical for all 10 investigated 
streams (Dumitriu, 2007; Rădoane et al. 2006). With the exception of Tazlău and Valea Rece basins, within the remaining basins the forested area accounts for more than $75 \%$ of the total basin area.

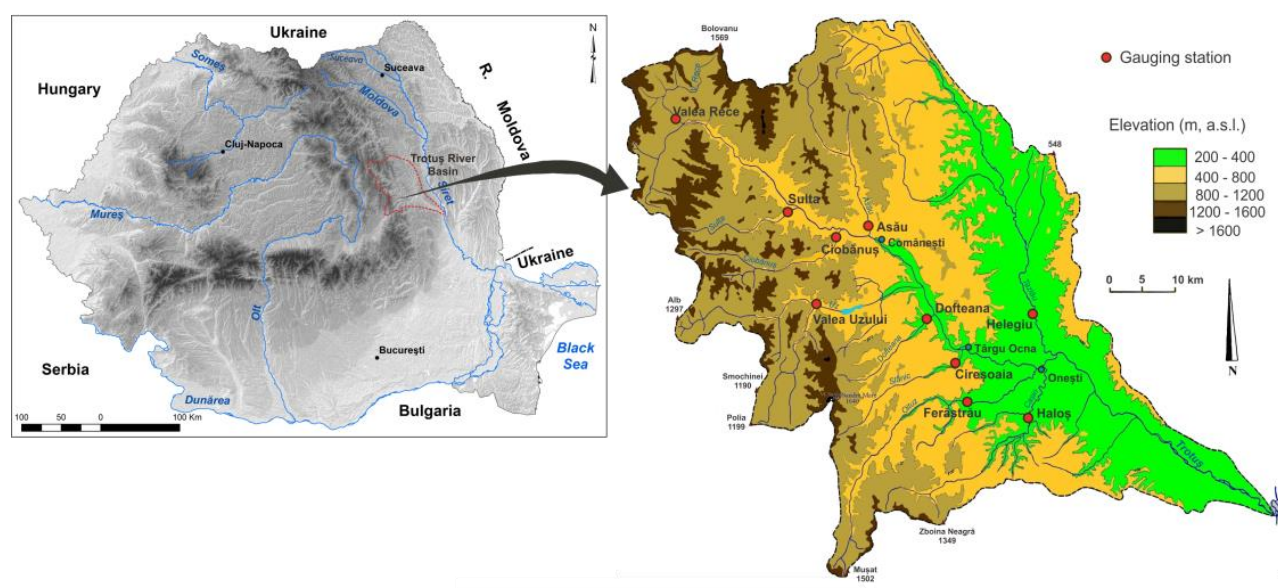

Figure 1. Location of the study area in Romania and location of gauging stations within Trotus drainage basin

\subsection{Data sources}

The data regarding streamflow (Q), and suspended sediment load (SSL) from 1994 to 2017 are provided by the "Romanian Waters" National Administration - Siret Water Branch, which manages the ten gauging stations included in this study. These data were examined statistically and were further used for the integrated analysis of streamflow and sediment load changes throughout the investigated time frame.

\subsection{Methods}

In this study, three types of trend methods were applied for testing. The nonparametric MK trend test was used to examine the occurrence of monotonic increasing or decreasing trends. The ȘSE method was applied in order to estimate the real slope of the linear trend. The ITM method was used to check the possible trends in Q and SSL data (Kiși et al. 2018).

\subsubsection{Mann-Kendall test}

The MK test was the most frequently used for assessing trends in hydroclimatic studies (Ali et al. 2019).

The MK test is applied in the situations where it is assumed that the values of the $x_{i}$ temporal data series conform to the following model: 


$$
x_{i}=f(t i)+\varepsilon_{i}
$$

where $f(t i)$ is a continuous monotonic time dependent function and $\varepsilon_{i}$ is residuals which are assumed to be from the same distribution having zero mean. Therefore, it is expected that the distribution's variance should be constant in time.

The aim is to test the null hypothesis of no trend, the null hypothesis $\left(\mathrm{H}_{0}\right)$, i.e. the data $x_{i}$ is randomly ordered in time, versus the alternative hypothesis $\left(\mathrm{H}_{1}\right)$ where an upward or downward monotonic trends exist. Hence, two statistics might be computed depending on the data length, the $S$ statistics provided by Gilbert (1987) and the $Z$ statistics. $S$ test is utilized for the time series having data points less than 10 , whereas normal approximation is utilized for the time series having 10 or more data points ( $n$ ) (Kiși et al. 2018).

The Mann-Kendall test statistic $S$ can be computed using the following formula:

$$
S=\sum_{j=1}^{n-1} \sum_{k=k+1}^{n} \operatorname{sgn}\left(x_{k}-x_{j}\right)
$$

In the above formula $x_{j}$ and $x_{k}$ are the data values at times $\mathrm{j}$ and $\mathrm{k}, \mathrm{j}>\mathrm{k}$, respectively, and

$$
\operatorname{sgn}\left(x_{k}-x_{j}\right)=\left\{\begin{array}{c}
+1 \text { when }\left(x_{k}-x_{j}\right)>0 \\
0 \text { when }\left(x_{k}-x_{j}\right)=0 \\
-1 \text { when }\left(x_{k}-x_{j}\right)<0
\end{array}\right.
$$

The variance of $S$ is estimated as:

$$
\operatorname{VAR}(S)=\frac{n(n-1)(2 n+5)-\sum_{p=1}^{q} t_{p}\left(t_{p}-1\right)\left(2 t_{p}+5\right)}{18}
$$

where $q$ denotes the number of tied groups and $t_{p}$ represents the number of data values in the $q^{\text {th }}$ set.

The standardized test static for the MK test $(Z)$ can be calculated, as shown in Eq. (5):

$$
Z=\left\{\begin{array}{l}
\frac{S-1}{\sqrt{V A R(S)}} \text { if } S>0 \\
0 \text { if } S=0 \\
\frac{S+1}{\sqrt{\operatorname{VAR}(S)}} \text { if } S<0
\end{array}\right.
$$


The sign of $\mathrm{Z}$ indicates the direction of the trend. The negative value of $\mathrm{Z}$ indicates a decreasing trend and positive value of $\mathrm{Z}$ indicates a increasing trend. Testing trends is performed at the specific $\alpha$ significance level. In this study, $\alpha=$ 0.05 was used. At the $5 \%$ significance level, the null hypothesis of no trend is rejected if $Z>1.96$. The significance of the change in annual Q and SSL was estimated using the MK test.

Data were processed using an Excel macro named Makesens created by Salmi et al. (2002).

\subsubsection{Estimation of magnitude of change}

The Sen's slope method (Sen, 1968) was used for the estimation of the change in annual Q and SSL for the period 1994-2017. The Sen's slope $(\beta)$ is calculated as the median of all the slopes estimated between all the successive data points of a river flow time series $\left(x_{i}\right)$ as (Ali et al. 2019):

$$
\beta=\operatorname{median}\left[\frac{\Delta y}{\Delta t}\right]
$$

where, $\Delta y$ is the change in Q or SSL due to the change in time, $\Delta t$, between two subsequent Q or SSL data. The Sen's slope is a non-parametric method which has been found highly reliable for estimation of change over time (Da Silva et al. 2015).

\subsubsection{Innovative trend method}

Innovative trend method (ITM) was first introduced by Şen (2012). In this method, data are equally divided into two segments between first dates to the last date. Both segments are arranged in ascending order and presented in the $\mathrm{X}$ and $\mathrm{Y}$-axis. The first segment $\left(x_{i}: \mathrm{i}=1,2, \ldots, n / 2\right)$ is presented in the horizontal axis while the second segment $\left(x_{\mathrm{j}}: \mathrm{j}=\mathrm{n} / 2+1, \mathrm{n} / 2+2, \ldots, \mathrm{n}\right)$ is presented in vertical axis in the Cartesian coordinate system. A bisector line at $1: 1\left(45^{\circ}\right)$ divides the diagram into two equal triangles. The upper triangle represents an increasing trend,while a lower one indicates a decreasing trend. If the points are concentrated along the median line, they do not indicate any trend. For the estimation of the trend, the $S_{\text {ITM }}$ statistic is computed as follows (Șen, 2017):

$$
S_{\text {ITM }}=\frac{2(\overline{x i}-\overline{x j})}{n}
$$

where $S_{\text {ITM }}$ is the slope base on the ITM method, $n$ is the sample size, $\bar{x}_{i}$ and $\bar{x}_{\mathrm{j}}$ are the mean value of the first and second half of the series, respectively. 
The standard deviation of sampling slope is calculated as:

$$
\sigma_{s}=\frac{2 \sqrt{2}}{n \sqrt{n}} \sigma \sqrt{1-} \rho \overline{x i x j}
$$

where $\sigma_{s}$ is the standard deviation of sampling slope; $\sigma$ is the standard deviation of whole data series; and $\rho_{x i}{ }^{i} j$ is the crosscorrelation coefficient between the ascendingly sorted two halves' arithmetic averages.

The confidence limits (upper and lower) of the trend slope at $\alpha$ level of significance are expressed using the following expression:

$$
C L_{1-\alpha}=0 \pm s \sigma_{s}
$$

where $C L$ is the upper and lower confidence limits at $\alpha$ level of significance; $\sigma_{s}$ is the standard deviation of sampling slope; and $s$ is the slope value. The null hypothesis $\left(\mathrm{H}_{\mathrm{o}}\right)$ is such that there is no trend in the time series, and alternate hypothesis $\left(\mathrm{H}_{1}\right)$ is such that there is a trend in the time series. Thus, in a twosided condition, the $\mathrm{H}_{\circ}$ and $\mathrm{H}_{1}$ are tested at $\alpha=5 \%$ with $\mathrm{Z}= \pm 1.96$. If $\pm s> \pm C L_{1}$ $\alpha$, then $\mathrm{H}_{0}$ is rejected and $\mathrm{H}_{1}$ is accepted. A positive (negative) value of $s$ indicates an increasing (decreasing) trend in the time series (Malik et al. 2019). In this study, the significance of the change in annual Q and SSL was estimated using ITM.

The statistical relation between SSL and Q, also known as the sediment rating curve, is typically determined using the power function (Asselman, 2000):

$$
S S L=\mathrm{aQ}^{\mathrm{b}}
$$

where SSL is the rate of the suspended sediment load; a - regression coefficient; $\mathrm{b}$ - regression exponent.

\section{RESULTS AND DISCUSSION}

In order to acquire a better understanding and perform an accurate analysis of streamflow and sediment load regimes during the studied time frame we used the descriptive statistics of data series characteristic for the two variables (Table 2 ). The data analysis revealed that the investigated basins can be ranked into three categories: (i) basins under $200 \mathrm{~km}^{2}$ in area, with average streamflow discharge below $2 \mathrm{~m}^{3} / \mathrm{s}$ and maximum streamflow below $100 \mathrm{~m}^{3} / \mathrm{s}$ (with the exception of Asău and Dofteana). This category includes basins from the upper and midcourse (upstream of Târgu Ocna); (ii) basins ranging between 200 and $300 \mathrm{~km}^{2}$ in area, with average multiannual streamflow values between 2 and 3 $\mathrm{m}^{3} / \mathrm{s}$ and maximum streamflow values higher than $300 \mathrm{~m}^{3} / \mathrm{s}$. This class comprises the basins of rivers Oituz and Cașin; (iii) Tazlău basin, with an area of ca. 1000 
$\mathrm{km}^{2}$ and a multiannual streamflow averaging at ca. $7 \mathrm{~m}^{3} / \mathrm{s}$, whereas the maximum streamflow in the studied period reached $1556 \mathrm{~m}^{3} / \mathrm{s}$.

Table 2. Descriptive statistics of annual discharge (1994-2017) and suspended sediment load at study gauging stations

\begin{tabular}{|c|c|c|c|c|c|c|}
\hline River & Gauging station & $\begin{array}{c}\text { Statistical } \\
\text { parameters }\end{array}$ & $\begin{array}{l}Q_{\text {mean }} \\
\left(\mathrm{m}^{3} / \mathrm{s}\right)\end{array}$ & $\begin{array}{c}\mathrm{Q}_{\max } \\
\left(\mathrm{m}^{3} / \mathrm{s}\right)\end{array}$ & $\begin{array}{c}\mathrm{SSL}_{\text {mean }} \\
(\mathrm{kg} / \mathrm{s})\end{array}$ & $\begin{array}{l}\mathrm{SSL}_{\text {max }} \\
(\mathrm{kg} / \mathrm{s})\end{array}$ \\
\hline \multirow{6}{*}{ Valea Rece } & \multirow{6}{*}{ Valea Rece } & Mean & 1.3 & 20.7 & & \\
\hline & & Standard Dev. & 0.4 & 19.7 & & \\
\hline & & Kurtosis & 0.0 & 4.1 & & \\
\hline & & Skewness & 0.9 & 2.2 & & \\
\hline & & Minimum & 0.7 & 5.6 & & \\
\hline & & Maximum & 2.4 & 78.1 & & \\
\hline \multirow{6}{*}{ Sulța } & \multirow{6}{*}{ Sulța } & Mean & 1.0 & 16.1 & & \\
\hline & & Standard Dev. & 0.3 & 18.6 & & \\
\hline & & Kurtosis & 1.2 & 3.8 & & \\
\hline & & Skewness & 0.9 & 2.2 & & \\
\hline & & Minimum & 0.6 & 3.0 & & \\
\hline & & Maximum & 1.8 & 71.2 & & \\
\hline \multirow{6}{*}{ Ciobănuș } & \multirow{6}{*}{ Ciobănuș } & Mean & 0.9 & 15.0 & & \\
\hline & & Standard Dev. & 0.3 & 12.8 & & \\
\hline & & Kurtosis & 0.1 & 2.7 & & \\
\hline & & Skewness & 0.2 & 1.8 & & \\
\hline & & Minimum & 0.2 & 3.4 & & \\
\hline & & Maximum & 1.6 & 52.6 & & \\
\hline \multirow{6}{*}{ Asău } & \multirow{6}{*}{ Asău } & Mean & 1.8 & 29.5 & 1.7 & 91.9 \\
\hline & & Standard Dev. & 0.7 & 38.1 & 1.2 & 82.7 \\
\hline & & Kurtosis & 1.1 & 18.3 & -0.2 & 7.1 \\
\hline & & Skewness & 1.2 & 4.1 & 0.8 & 2.2 \\
\hline & & Minimum & 1.1 & 8.3 & 0.2 & 3.5 \\
\hline & & Maximum & 3.7 & 198.0 & 4.5 & 394.0 \\
\hline \multirow{6}{*}{$\mathrm{Uz}$} & \multirow{6}{*}{ Valea Uzului } & Mean & 1.4 & 21.7 & 0.7 & 42.4 \\
\hline & & Standard Dev. & 0.6 & 13.0 & 0.7 & 56.6 \\
\hline & & Kurtosis & 0.5 & 3.1 & 0.3 & 12.0 \\
\hline & & Skewness & 0.6 & 1.6 & 1.2 & 3.1 \\
\hline & & Minimum & 0.5 & 6.2 & 0.04 & 1.7 \\
\hline & & Maximum & 3.0 & 62.5 & 2.4 & 272.0 \\
\hline \multirow{6}{*}{ Dofteana } & \multirow{6}{*}{ Dofteana } & Mean & 0.9 & 29.7 & & \\
\hline & & Standard Dev. & 0.4 & 31.7 & & \\
\hline & & Kurtosis & 3.8 & 5.5 & & \\
\hline & & Skewness & 1.6 & 2.3 & & \\
\hline & & Minimum & 0.4 & 5.4 & & \\
\hline & & Maximum & 2.1 & 138.0 & & \\
\hline \multirow{6}{*}{ Slănic } & \multirow{6}{*}{ Cireșoaia } & Mean & 1.1 & 23.5 & & \\
\hline & & Standard Dev. & 0.3 & 22.3 & & \\
\hline & & Kurtosis & -0.2 & 4.8 & & \\
\hline & & Skewness & 0.6 & 2.1 & & \\
\hline & & Minimum & 0.6 & 4.7 & & \\
\hline & & Maximum & 1.8 & 98.8 & & \\
\hline
\end{tabular}


Streamflow and suspended sediment load trends in Trotus drainage basin: Geomorphic implications

\begin{tabular}{|c|c|c|c|c|c|c|}
\hline \multirow{6}{*}{ Oituz } & \multirow{6}{*}{ Ferăstrău } & Mean & 2.7 & 47.7 & 1.2 & 124.7 \\
\hline & & Standard Dev. & 0.9 & 36.3 & 1.3 & 206.5 \\
\hline & & Kurtosis & 0.1 & 3.6 & 6.9 & 17.5 \\
\hline & & Skewness & 0.7 & 1.7 & 2.5 & 4.0 \\
\hline & & Minimum & 1.5 & 9.8 & 0.3 & 4.0 \\
\hline & & Maximum & 5.0 & 311.0 & 5.8 & 1030.0 \\
\hline \multirow{6}{*}{ Caşin } & \multirow{6}{*}{ Haloș } & Mean & 2.1 & 81.2 & & \\
\hline & & Standard Dev. & 0.8 & 101.2 & & \\
\hline & & Kurtosis & 1.4 & 5.0 & & \\
\hline & & Skewness & 1.1 & 2.2 & & \\
\hline & & Minimum & 0.9 & 8.9 & & \\
\hline & & Maximum & 4.4 & 419.0 & & \\
\hline \multirow{6}{*}{ Tazlău } & \multirow{6}{*}{ Helegiu } & Mean & 6.4 & 279.6 & 5.3 & 1671.1 \\
\hline & & Standard Dev. & 2.9 & 407.6 & 5.4 & 4030.0 \\
\hline & & Kurtosis & 0.4 & 5.7 & 5.4 & 19.7 \\
\hline & & Skewness & 1.0 & 2.5 & 2.3 & 4.3 \\
\hline & & Minimum & 3.1 & 18.6 & 0.5 & 16.8 \\
\hline & & Maximum & 13.8 & 1556.0 & 23.6 & 19800.0 \\
\hline
\end{tabular}

\subsection{River flow trends}

The MK trend test was applied for the data series of the average annual streamflow values at all gauging stations comprised in the study. The tests were applied for confidence intervals of $90 \%, 95 \%$ and $99 \%$. The results yielded by this approach are shown in Table 3 and reveal negative (decreasing) trends at all stations, with the sole exception of Helegiu gage on river Tazlău, where a positive (increasing) trend was documented.

Table 3. Mann-Kendall test and Sen's slope statistics of mean annual discharge

\begin{tabular}{|c|c|c|c|c|}
\hline \multirow{2}{*}{ Gauging station } & \multicolumn{2}{|c|}{ Mann-Kendall test } & \multirow{2}{*}{ Sen's slope } & \multirow{2}{*}{ Trend } \\
\cline { 2 - 3 } & $\mathrm{Z}$ & P-value & -0.02 & Downward \\
\hline Valea Rece & -1.91 & 0.06 & -0.01 & Downward \\
\hline Sulța & -0.52 & 0.60 & -0.01 & Downward \\
\hline Ciobănuș & -0.32 & 0.63 & -0.02 & Downward \\
\hline Asău & -1.07 & 0.29 & -0.03 & Downward \\
\hline Valea Uzului & -1.27 & 0.21 & -0.01 & Downward \\
\hline Dofteana & -0.52 & 0.60 & -0.01 & Downward \\
\hline Cireșoaia & -1.07 & 0.29 & -0.03 & Downward \\
\hline Ferăstrău & -0.77 & 0.44 & -0.01 & Downward \\
\hline Haloș & -0.27 & 0.78 & 0.05 & Upward \\
\hline Helegiu & 0.97 & 0.33 & & \\
\hline
\end{tabular}

The results of Șen's trend test are also shown in Table 3 (column 3) and reveal the same decreasing trend of streamflow discharge, with the exception of Helegiu (Tazlău) gauging station where the trend was upward. The downward slope is not steep, and the documented trend is a slow progressive decrease. However, more abrupt downward trends were observed at Valea Rece, Asău, Uz 
and Oituz gauging stations. The upward trend recorded at Helegiu gage is more evident compared to the decreasing trends observed at the other 9 stations (Figure 2).
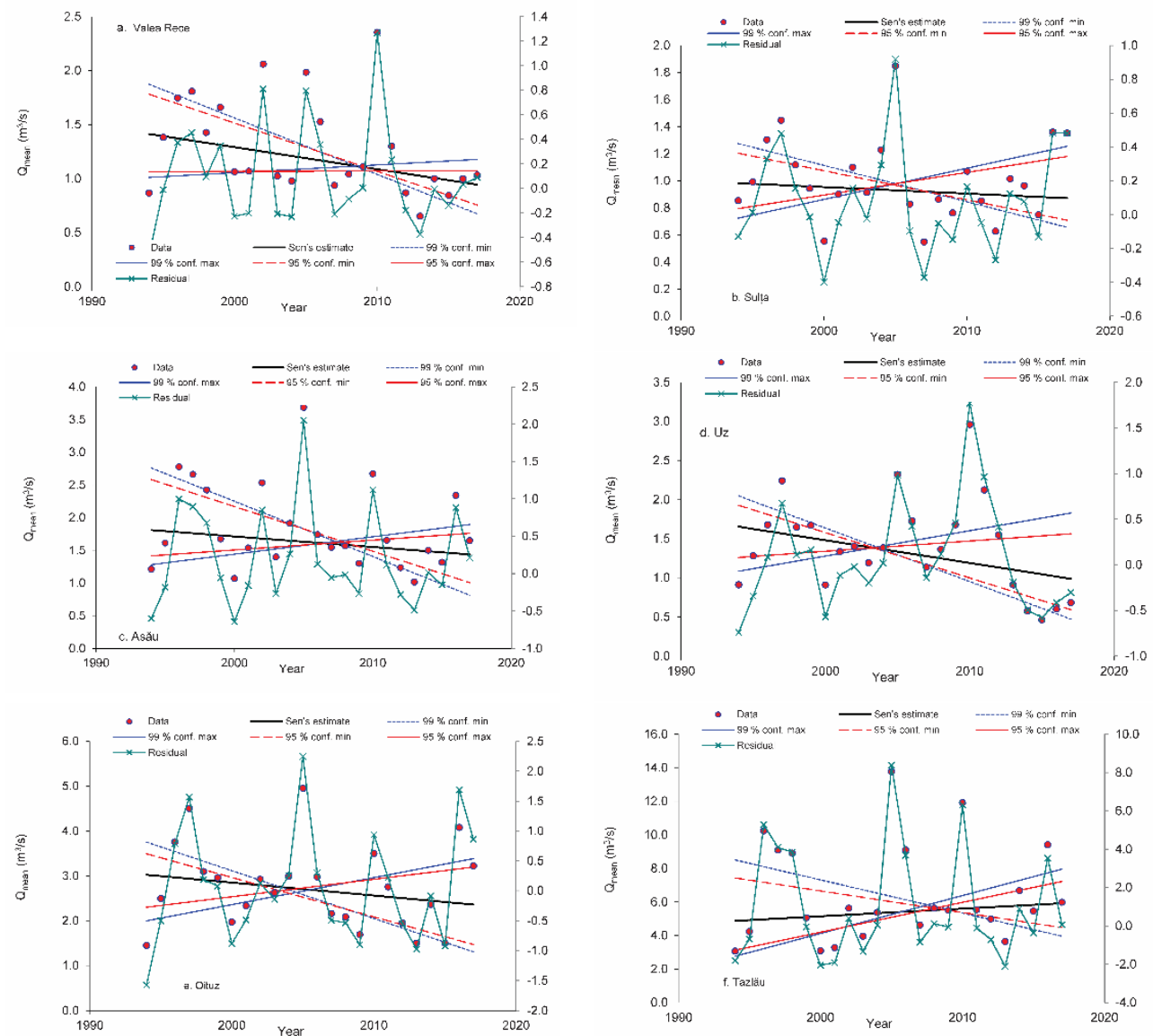

Figure 2. Annual time series and trend statistics of annual streamflow during 1994-2017

The results yielded by ITM are similar to the ones generated by the MK and ȘSE tests only in the case of mean multiannual streamflow discharge. The maximum annual streamflow differs in terms of trends (Table 4, Figure 3). Thus, the downward trend of the maximum streamflow was documented solely in the case of tributaries from the mid part of Trotuș drainage basin (Ciobănuș, Asău and Valea Uzului). By contrast, evident upward trends for the maximum 
streamflow were observed at Halos and Helegiu gauging stations. At stations pertaining to the latter category the increasing trend of maximum streamflow was in fact characteristic only for median and upper classes, whereas at most gages the lower classes of maximum streamflow showed no visible trend or a slow decrease.

Table 4. The results of innovative trend analysis on mean and maximum annual discharge

\begin{tabular}{|c|c|c|c|c|c|c|c|}
\hline Gauging station & Variables & Slope $(s)$ & $\sigma$ & $\rho \overline{\mathrm{y} 1} \overline{\mathrm{y} 2}$ & $\sigma_{\mathrm{s}}$ & Upper CL & $\begin{array}{c}\text { Lower } \\
\text { CL }\end{array}$ \\
\hline \multirow{2}{*}{ Valea Rece } & Qmean & $-0.02 *$ & 0.45 & 0.811 & 0.005 & 0.01 & -0.01 \\
\hline & Qmax & $1.10 *$ & 19.67 & 0.850 & 0.18 & 0.36 & -0.36 \\
\hline \multirow{2}{*}{ Sulța } & Qmean & $-0.02 *$ & 0.30 & 0.958 & 0.001 & 0.003 & -0.003 \\
\hline & Qmax & 0.18 & 18.57 & 0.804 & 0.20 & 0.39 & -0.39 \\
\hline \multirow{2}{*}{ Ciobănuș } & Qmean & -0.01 & 0.35 & 0.893 & 0.003 & 0.01 & -0.01 \\
\hline & Qmax & $-0.56^{*}$ & 12.76 & 0.914 & 0.09 & 0.18 & -0.18 \\
\hline \multirow{2}{*}{ Asău } & Qmean & $-0.03^{*}$ & 0.66 & 0.936 & 0.004 & 0.01 & -0.01 \\
\hline & Qmax & $-1.34 *$ & 38.08 & 0.859 & 0.34 & 0.67 & -0.67 \\
\hline \multirow{2}{*}{$\begin{array}{l}\text { Valea } \\
\text { Uzului }\end{array}$} & Qmean & $-0.02 *$ & 0.61 & 0.959 & 0.00 & 0.01 & -0.01 \\
\hline & Qmax & -0.15 & 12.99 & 0.920 & 0.09 & 0.17 & -0.17 \\
\hline \multirow{2}{*}{ Dofteana } & Qmean & $-0.02 *$ & 0.37 & 0.959 & 0.002 & 0.004 & 0.00 \\
\hline & Qmax & $1.20 *$ & 31.69 & 0.773 & 0.36 & 0.71 & -0.71 \\
\hline \multirow{2}{*}{ Cireșoaia } & Qmean & $-0.02 *$ & 0.32 & 0.930 & 0.002 & 0.004 & -0.004 \\
\hline & Qmax & $1.31 *$ & 22.32 & 0.974 & 0.09 & 0.17 & -0.17 \\
\hline \multirow{2}{*}{ Ferăstrău } & Qmean & $-0.04 *$ & 0.94 & 0.963 & 0.004 & 0.01 & -0.01 \\
\hline & Qmax & 0.97 & 36.30 & 0.659 & 0.51 & 1.00 & -1.00 \\
\hline \multirow[t]{2}{*}{ Haloş } & Qmean & $-0.03^{*}$ & 0.81 & 0.978 & 0.003 & 0.01 & -0.01 \\
\hline & Qmax & $6.01 *$ & 101.24 & 0.920 & 0.69 & 1.35 & -1.35 \\
\hline \multirow{2}{*}{ Helegiu } & Qmean & 0.02 & 2.88 & 0.963 & 0.01 & 0.03 & -0.03 \\
\hline & Qmax & $12.00^{*}$ & 407.65 & 0.908 & 2.97 & 5.83 & -5.83 \\
\hline
\end{tabular}

*Statistically significant at $\alpha=5 \%$ (critical $Z= \pm 1.96$ )

The downward trend of streamflow discharge can be related to the increasing trend of temperature and the diminishing amounts of precipitation (Kahya and Kalayci, 2004; Da Silva et al. 2015). The current state of Trotuss drainage basin is very well correlated with the data provided by Rădoane et al. (2013) regarding the annual trend of precipitation between 1950 and 2010 at 29 gauging stations within Siret drainage basin. The precipitation trend was estimated based on the $b$ coefficient (the slope) of the linear regression. Depending on its value, the following trends were delineated: positive $(b>0.5)$, relatively stationary $(0.5<b>-0.5)$ and negative $(b<-0.5)$ trend. This method was employed in other climatological studies in Romania, as well (Apostol, 2000; Busuioc et al. 2010). In the case of Trotus drainage basin (with the exception of river Tazlău) values below -0.5 are prevalent, which indicates a downward trend in precipitation, which further explains the decreasing trend of streamflow discharge. In Tazlău drainage basin the $b$ coefficient is higher than 0 , 

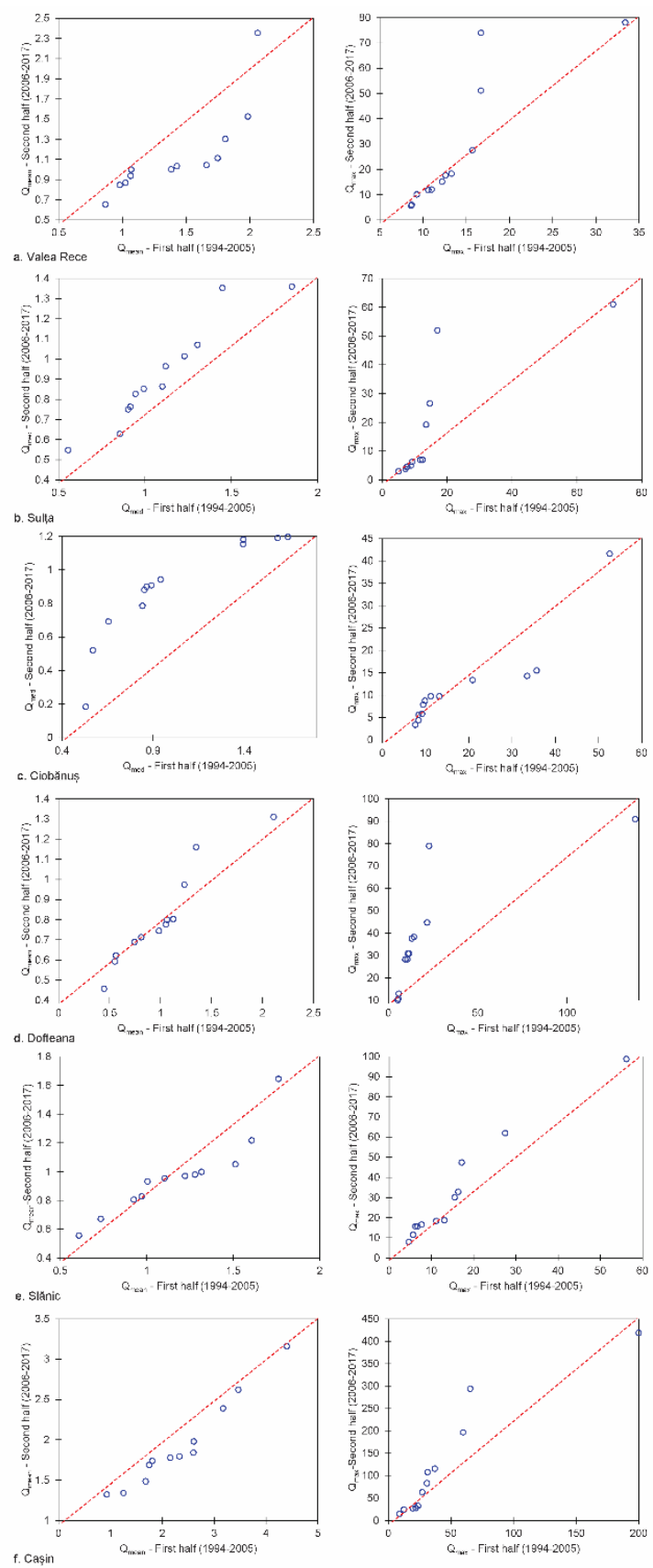

Figure 3. The results of ITM for mean and maximum annual discharge 
which points to an upward trend of the streamflow. As regards the trend of the maximum streamflow, the correlation between the former and extreme precipitation is good (Croitoru et al., 2016). The downward trend of maximum streamflow discharge at gauging stations from the mid part of the drainage basin can be attributed to the 'shade' effect manifested in relation to the extreme precipitation generated by Atlantic (in western and central Romania) and Mediterranean (in eastern Romania) cyclones (Apostol, 2008; Dobri et al., 2017). At Helegiu and Halos stations, both located in the area affected by extreme rainfall generated by Mediterranean cyclones, the upward trend of maximum streamflow is evident.

Minea and Chelariu (2020) reveal that the same general downward trend of mean multiannual streamflow is maintained in eastern Romania.

\subsection{Annual trends of suspended sediment load}

The trends of the suspended sediment load determined using the MK and ȘSE tests are shown in Table 5. Unlike the streamflow discharge, the data indicate an upward trend at all stations (Figure 4).

Table 5. Mann-Kendall test and Sen's slope statistics of mean annual suspended sediment load

\begin{tabular}{|c|c|c|c|c|}
\hline \multirow{2}{*}{ Gauging station } & \multicolumn{2}{|c|}{ Mann-Kendall test } & \multirow{2}{*}{ Sen's slope } & \multirow{2}{*}{ Trend } \\
\hline & $\mathrm{Z}$ & $\mathrm{P}$-value & & \\
\hline Asău & 1.66 & 0.10 & 0.07 & Upward \\
\hline Valea Uzului & 3.35 & 0.00 & 0.04 & Upward \\
\hline Ferăstrău & 2.01 & 0.04 & 0.03 & Upward \\
\hline Helegiu & 0.87 & 0.39 & 0.07 & Upward \\
\hline
\end{tabular}

Similar results were yielded by ITM (Table 6, Figure 5). Statistically significant increases were documented at Asău and Valea Uzului gauging stations, which could indicate that the rise is more evident when the area of the drainage basins located upstream of the gages is smaller in size. In the case of Ferăstrău and Helegiu gauging stations, which monitor the hydrological effects across larger basins, the SSL increase was more moderate. The maximum annual suspended sediment load are diminishing only in the case of Asău River, whereas at the remaining gages the upward trends are more or less marked. 

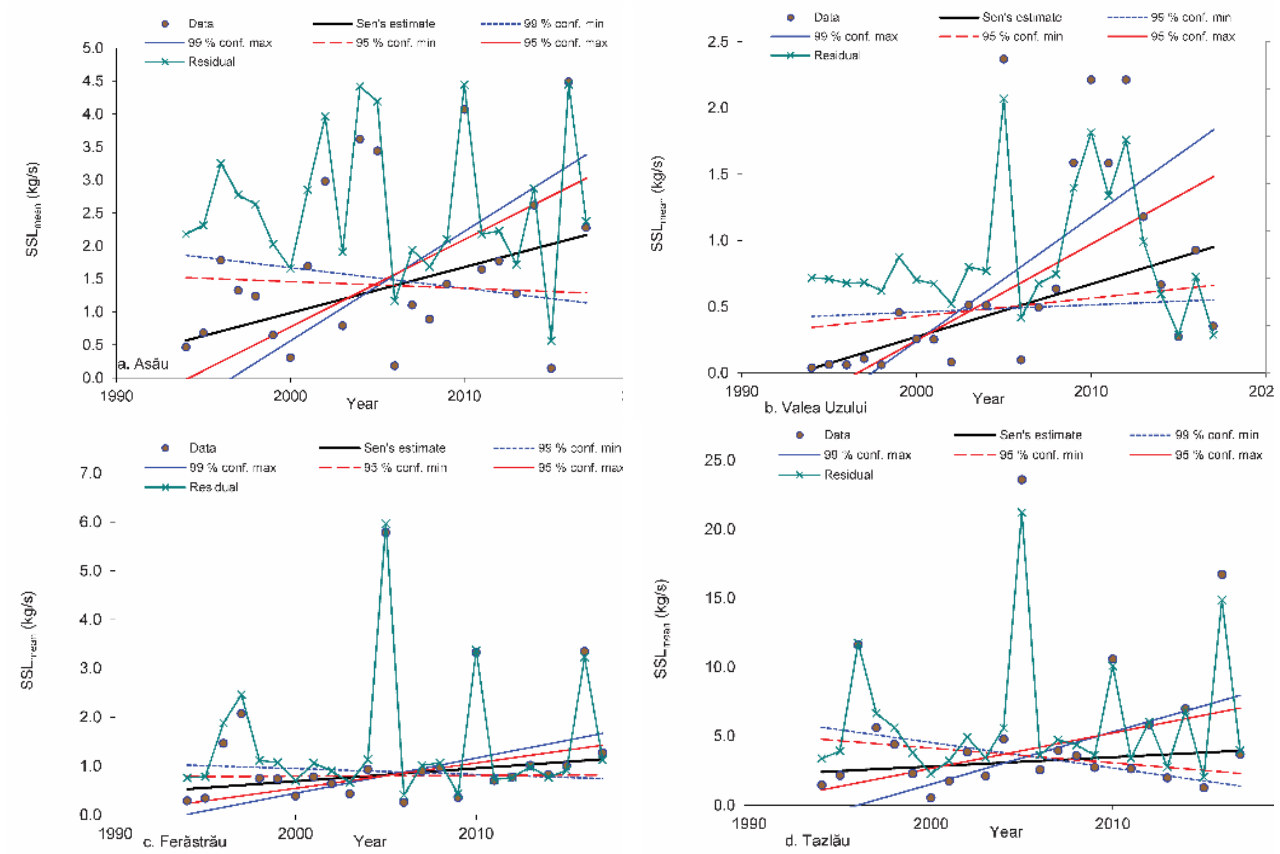

Figure 4. Annual time series and trend statistics of SSL during 1994-2017

Table 6. The results of innovative trend analysis on mean and maximum annual suspended sediment load

\begin{tabular}{|c|c|c|c|c|c|c|c|}
\hline \multirow{2}{*}{ Gauging station } & Variables & $\begin{array}{c}\text { Slope } \\
(s)\end{array}$ & $\sigma$ & $\rho \overline{\mathrm{y} 1} \overline{\mathrm{y} 2}$ & $\sigma_{\mathrm{s}}$ & $\begin{array}{c}\text { Upper } \\
\text { CL }\end{array}$ & $\begin{array}{c}\text { Lower } \\
\text { CL }\end{array}$ \\
\hline \multirow{2}{*}{ Asău } & SSLmean & $0.03^{*}$ & 1.25 & 0.969 & 0.01 & 0.01 & -0.01 \\
\hline \multirow{2}{*}{$\begin{array}{c}\text { Valea } \\
\text { Uzului }\end{array}$} & SSLmax & -1.00 & 82.66 & 0.836 & 0.80 & 1.58 & -1.58 \\
\hline \multirow{2}{*}{ Ferăstrău } & SSLmean & $0.05^{*}$ & 0.75 & 0.725 & 0.01 & 0.02 & -0.02 \\
\hline & SSLmax & 1.11 & 56.58 & 0.628 & 0.83 & 1.63 & -1.63 \\
\hline \multirow{2}{*}{ Helegiu } & SSLmean & 0.001 & 1.27 & 0.850 & 0.01 & 0.02 & -0.02 \\
\cline { 2 - 9 } & SSLmax & 4.40 & 206.46 & 0.741 & 2.53 & 4.96 & -4.96 \\
\cline { 2 - 9 } & SSLmean & 0.01 & 5.42 & 0.983 & 0.02 & 0.03 & -0.03 \\
\hline
\end{tabular}

*Statistically significant at $\alpha=5 \%$ (critical $Z= \pm 1.96$ )

The increasing trend of the suspended sediment load (SSL) was also documented by Rădoane et al. (2013). The authors took into account the data from the gauging stations located on river Trotuş (Lunca de sus, Goioasa, Târgu Ocna and Vrânceni). 

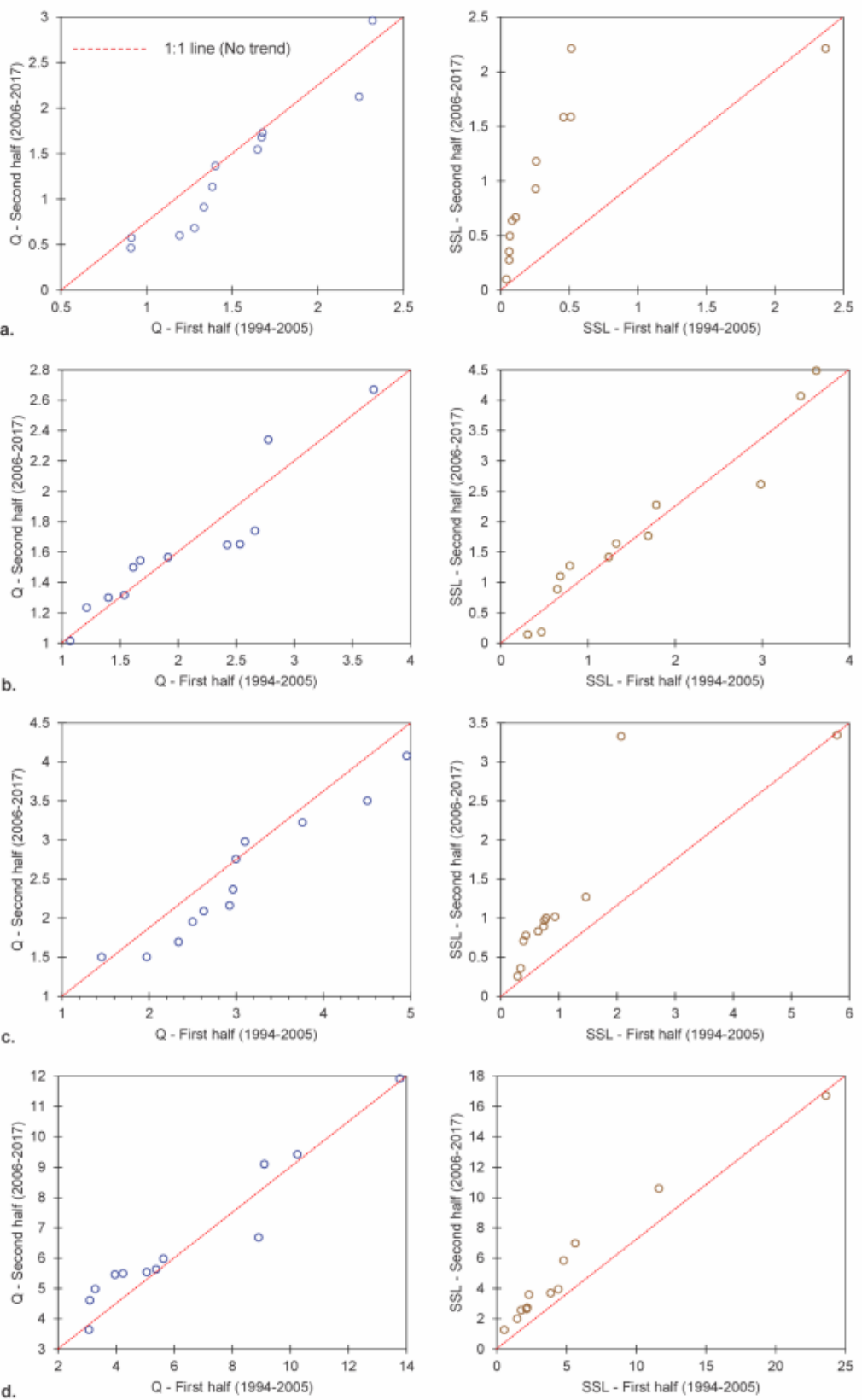

Figure 5. The results of ITM for $\mathrm{Q}_{\text {mean }}$ and $\mathrm{SSL}_{\text {mean }}$ (a) Asău; (b) Valea Uzului; (c) Ferăstrău; (d) Helegiu. 


\subsection{Correlations between $Q$ and SSL}

The studies carried out in the last half century revealed that the trend of the sediment flow is directly related to the anthropogenic impact (e.g. dam construction, land use/land cover changes, mining and gravel mining from channel beds, soil erosion control etc.) and climate changes. Some shifts (either anthropogenic or climatic) resulted in increasing sediment yields, whereas others (including mainly the construction of dams) led to a decrease in the sediment flow. In many instances it proves difficult to clearly distinguish between the causes (anthropogenic or climatic) which have determined either a rise or a drop in the sediment flow (Walling and Fang, 2003).

At gauging stations located on the main tributaries of Trotuss River the main general trends documented by this study were the decreasing $Q$ and increasing SSL. The correlations between Q and SSL trends (Figure 6) indicate that at the stations where the area of the monitored basin is small (Valea Uzului, Asău) the correlation coefficients $\left(\mathrm{R}^{2}\right)$ are below 0.500 , due to the fact that SSL trends reflect the $\mathrm{Q}$ trends to a much lower extent. In the case of larger drainage basins, the correlation coefficients have values higher than 0.005 , which indicates that $\mathrm{Q}$ and SSL are more closely related.
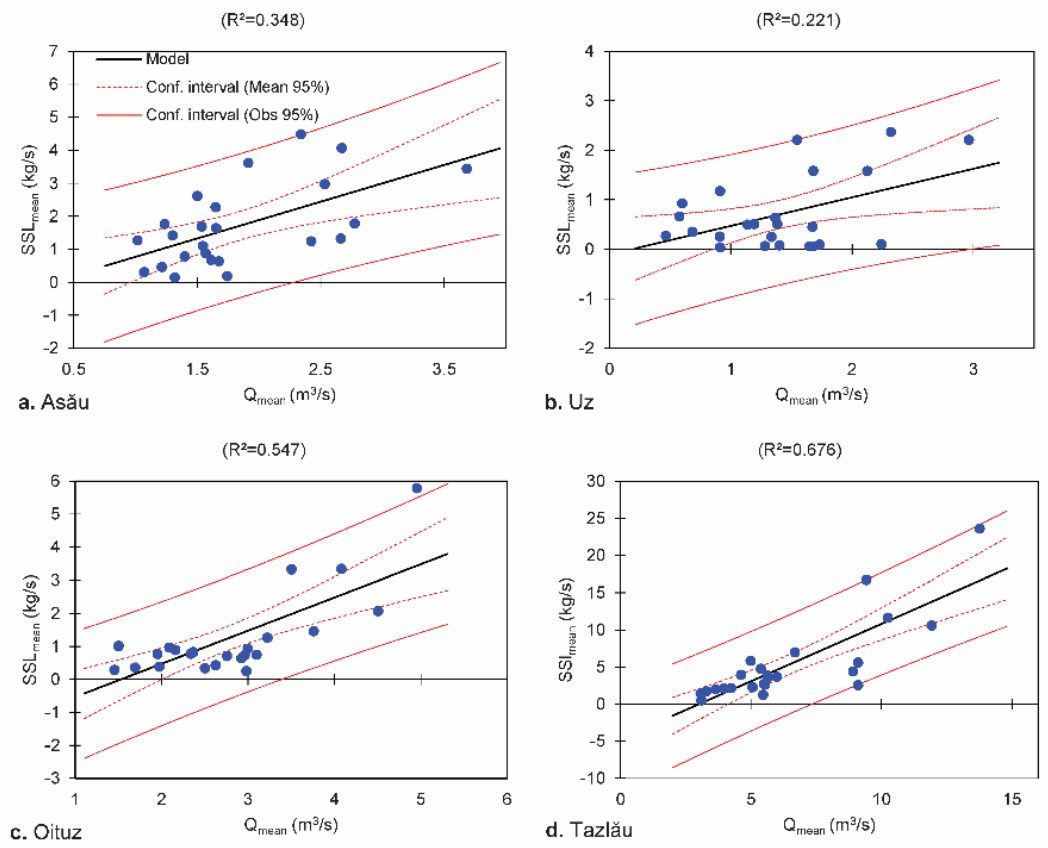

Figure 6. Correlation between Q and SSL 
The downward Q trend at the ten gauging stations of the study area can be linked to the decreasing precipitation trend in the area of Trotus drainage basin. However, the question remains whether the increasing SSL trend can be attributed to climate changes or to the anthropogenic impact?

The anthropogenic impact of the last two decades in the basins investigated in this study cannot explain the upward trend of SSL. The only anthropogenic intervention which could have resulted in a SSL increase is deforestation. However, the scale of forest removal in these basins (Rădoane et al. 2013) could not have influenced the SSL trend to this extent. In many scientific publications (mostly Romanian) the increasing streamflow and sediment load values are attributed to deforestation, albeit without presenting conclusive evidence to this support this hypothesis. Several studies show that in some instances forest logging does not lead to a rise of SSL (Arismendi et al. 2017; Hatten et al. 2018), whereas others reveal that deforestation can result in significant SSL increase of 3 up 12 times (Beschta, 1978; Grant and Wolff, 1991). "The variability in response to forest harvesting may be due, in part, to the multitude of variables that influence suspended sediment yields. For example, catchment lithology, physiography, land cover, land use, and hydrologic conditions may all impact suspended sediment" (Bywater-Reyes et al. 2018).

In our view, the stages of the reversal of SSL trend after 1989 were the following: the first stage was characterized by a general upward trend of the maximum streamflow under the direct influence of the increasing magnitude of extreme precipitation; the second stage was marked by the onset of river channel adjustments triggered by flood events (Dumitriu, 2016; 2018). These channel changes (widening, aggradation, degradation) resulted in the availability of sediment sources within the channel which further reflected in the sediment regime; in the current stage, the same streamflow discharge transports larger amounts of sediment. All these changes define the upward trend of SSL. To sum up, climate changes strongly influenced geomorphic processes occurring in river channels, which contributed to the overall increasing trend of SSL.

\section{Conclusions}

This study set out to analyze from a geomorphic viewpoint the trends of the streamflow and sediment load characteristic for the major tributaries of river Trotus. Three methods for trend testing were under scrutiny: Mann-Kendall trend test, Șen's slope estimator and the innovative trend method. The results yielded by the three approaches attest that the general trend (between 1994 and 2017) of the mean annual streamflow is downward, whereas the maximum annual streamflow is increasing. These trends were linked to the diminishing of 
mean annual precipitation, as well as to the increasing magnitude of extreme precipitation. Depending on the location of investigated basins, some exceptions to this overall trends occur due to the amounts of precipitation generated by Atlantic and Mediterranean cyclones. The suspended sediment load had an upward trend at all gauging stations of the study area, which is likely related to the changes occurring in channel beds as a result of major flood events. These shifts led to an increase in the availability of new sediment sources within the channels and thus to a rise in the sediment transport.

\section{References}

Ali, R., Kuriqi, A., Abubaker, S.R., Kisi, O. (2019), Long-term trends and seasonality detection of the observed flow in Yangtze River using Mann-Kendall and Șen's innovative trend method. Water, 11, 1855, https://doi.org/10.3390/w11091855

Ali, R., Abubaker, S.R. (2019), Trend analysis using Mann-Kendall, Șen's slope estimator test and innovative trend analysis method in Yangtze river basin, China: review. Int. J. Eng. Technol. 8, 110-119, [link]

Apostol, L. (2000), Precipitațiile atmosferice în Subcarpații Moldovei (Precipitations in Moldovei Subcarpathians). Editura Universității, Suceava, 236 pp. (in Romanian).

Apostol, L. (2008), The Mediterranean cyclones - the role in ensuring water resources and their potential of climatic risk, in the East of Romania. Present Environ. Sustain. Dev. 2, 143-163, [link]

Arismendi, I., Groom, J.D., Reiter, M., Johnson, S.L., Dent, L., Meleason, M., Argerich, A., Skaugset, A.E. (2017), Suspended sediment and turbidity after road construction/improvement and forest harvest in streams of the Trask River Watershed Study,Oregon. Water Resour. Res. 53, 6763-6783, https://doi.org/10.1002/2016WR020198

Asselman, N.E.M. (2000), Fitting and interpretation of sediment rating curves. J. Hydrol. 234, 228-248, https://doi.org/10.1016/S0022-1694(00)00253-5

Barnett, T.P., Adam, J.C., Lettenmaier, D.P. (2005), Potential impacts of a warming climate on water availability in snow-dominated regions. Nature 438 (7066), 303309, https://doi.org/10.1038/nature04141

Beschta, R.L. (1978), Long-term patterns of sediment production following road construction and logging in the Oregon Coast Range. Water Resour. Res. 14, 10111016, https://doi.org/10.1029/WR014i006p01011

Bîrsan, M.V., Zaharia, Liliana, Chendes, V., Branescu E. (2012) Recent trends in streamflow in Romania (1976-2005). Rom. Rep. Phys. 64, 275-280 [link]

Bîrsan, M.V., Zaharia, Liliana, Chendes, V., Branescu, E. (2014), Seasonal trends in Romanian streamflow. Hydrol. Process. 28, 4496-4505, https://doi.org/10.1002/hyp.9961

Bîrsan, M.V. (2015), Trends in monthly natural streamflow in Romania and linkages to atmospheric circulation inthe North Atlantic.Water Resources Management 29, 3305-3313, https://doi.org/10.1007/s11269-015-0999-6 
Busuioc, A., Caian, M., Cheval, S., Bojariu, R., Boroneant, C., Baciu, M., Dumitrescu, A. (2010), Climate variability and change in Romania. Editura Pro Universitaria, Bucharest, 228 pp. (in Romanian).

Bywater-Reyes, S., Bladon, K.D., Segura, C. (2018), Relative influence of landscape variables and discharge on suspended sediment yields in temperate mountain catchments. Water Resour. Res. 54, 5126-5142, https://doi.org/10.1029/2017WR021728

Croitoru, A.E., Minea, I. (2015) The impact of climate changes on rivers discharge in Eastern Romania. Theor. Appl. Climatol. 120, 563-573, https://doi.org/10.1007/s00704-014-1194-z

Croitoru, A.E., Piticar, A., Burada, D.C. (2016), Changes in precipitation extremes in Romania. Quaternary International 415, 325-335, https://doi.org/10.1016/j.quaint.2015.07.028

Da Silva, R.M., Santos, C.A.G., Moreira, M., Corte-Real, J., Silva, V.C.L., Medeiros, I.C. (2015), Rainfall and river flow trends using Mann-Kendall and Sen's slope estimator statistical tests in the Cobres River basin. Nat. Hazards 77, 1205-1221, DOI: https://doi.org/10.1007/s11069-015-1644-7

Dey, P., Mishra, A. (2017), Separating the impacts of climate change and human activities on streamflow: A review of methodologies and critical assumptions. J. Hydrol. 548, 278-290, https://doi.org/10.1016/j.jhydrol.2017.03.014

Dobri, R.V., Sfîca, L., Ichim, P., Harpa, G.V. (2017), The distribution of the monthly 24-hour maximum amount of precipitation in Romania according to their synoptic causes. Geogr. Tech. 12, 62-72, DOI: 10.21163/GT_2017.122.06

Dumitriu, D. (2007), Sediment system of the Trotuş drainage basin. Editura Universităţii, Suceava, 259 p. (in Romanian).

Dumitriu, D. (2014), Source area lithological control on sediment delivery ratio in Trotuş drainage basin (Eastern Carpathians). Geogr. Fis. Din. Quat. 37, 91-10, [link]

Dumitriu, D. (2016), Geomorphic effectiveness of floods on Trotuş River channel (Romania) between 2000 and 2012. Carpath. J. Earth. Env. 11, 181-196 [link]

Dumitriu, D. (2018), Sub-bankfull flow frequency versus magnitude of flood events in outlining effective discharges. Case Study: Trotuş River (Romania). Water 10, 1292, https://doi.org/10.3390/w10101292

Dumitriu, D., Rădoane, Maria, Rădoane, N. (2017), Sediment sources and delivery. In Landform Dynamics and Evolution in Romania, Rădoane, M., Vespremeanu-Stroe, A. (Eds.), Springer, pp. 629-654, https://doi.org/10.1007/978-3-319-32589-7_27

Gilbert, R.O. (1987), Statistical methods for environmental pollution monitoring. New Van Nostrand Reinhold, New York, 320 p.

Grant, G.E., Wolff, A.L. (1991), Long-term patterns of sediment transport following timber harvest, Western Cascade Mountains, Oregon. In: Sediment and streamwater quality in a changing environment: trends and explanation (Vol. 203, pp. 31-41). Vienna: IAHS, [link]

Guo, L., Yu, Q., Gao, P., Nie, X., Liao, K., Chen, X., Hu, J., Mu, X. (2018), Trend and change-point analysis of streamflow and sediment discharge of the Gongshui 
River in China during the last 60 years. Water 10 (9), 1273, https://doi.org/10.3390/w10091273

Hatten, J.A., Segura, C., Bladon, K.D., Hale, V.C., Ice, G.G., Stednick, J.D. (2018), Effects of contemporary forest harvesting on suspendedsediment in the Oregon Coast Range: Alsea Watershed Study Revisited. Forest Ecol. Manag. 408, 238-248, https://doi.org/10.1016/j.foreco.2017.10.049

Ioniță, M. (2015), Interannual summer streamflow variability over Romania and its connection to large-scale atmospheric circulation. Int. J. Climatol. 35,4186-4196, https://doi.org/10.1002/joc.4278

Ioniță, M., Chelcea, S., Rimbu, N., Adler M.J. (2014), Spatial and temporal variability of winter streamflow over Romania and its relationship to large-scale atmospheric circulation. J. Hydrol. 519, 1339-1349, https://doi.org/10.1016/j.jhydrol.2014.09.024

Kiși, O., Santos, C.A.G., Silva, R.M.D., Zounemat-Kermani, M. (2018), Trend analysis of monthly streamflows using Şen's innovative trend method. Geofizika 35(1), 53-68, https://doi.org/10.15233/gfz.2018.35.3

Liu, T., Huang, H. Q., Shao, M., Yao, W., Gu, J., Yu, G. (2005), Responses of streamflow and sediment load to climate change and human activity in the Upper Yellow River, China: a case of the Ten Great Gullies Basin.Water Sci.Technol.71(12), 1893-1900, https://doi.org/10.2166/wst.2015.167

Malik, A., Kumar, A., Guhathakurta, P., Kisi, O. (2019), Spatial-temporal trend analysis of seasonal and annual rainfall (1966-2015) using innovative trend analysis method with significance test. Arab. J. Geosci. 12, 328, 2-23, https://doi.org/10.1007/s12517-019-4454-5

Milliman, J.D., Meade, R.H. (1983), World-wide delivery of river sediment to the oceans. Journal of Geology 9, 1-21, https://doi.org/10.1086/628741

Minea, I., Chelariu, Oana Elena (2020), Anomalies and trends of high river flow under temperate climatic conditions in north-eastern Romania. Journal of Water and Climate Change, doi: https://doi.org/10.2166/wcc.2020.124

Rădoane, Maria, Rădoane, N., Dumitriu, D., Miclăuş, Crina (2006), Bimodality origin of fluvial bed sediments. Study case: East Carpathian rivers. Carpath. J. Earth. Env. 1, 13-38.

Rădoane, N., Rădoane, Maria, Olariu, P., Dumitriu, D. (2006). Efectele geomorfologice ale inundatiilor din 28-29 iulie 2004 în bazine hidrografice mici din Valea Trotuşului. Geografia în contextual dezvoltării durabile, Univ. „BabeşBolyai" Cluj Napoca, pp. 43-52, Presa Universitară Clujeană Publishing.

Rîmbu, N., Boroneant, C., Buta, C., Dima, M. (2002), Decadal variability of the Danube river flow in the lower basin and its relation with the North Atlantic Oscillation. Int J. Climatol. 22,1169-1179, https://doi.org/10.1002/joc.788

Rîmbu, N., Dima, M., Lohmann, G., Ștefan, S. (2004), Impacts of the North Atlantic Oscillation and the El Niño-Southern Oscillation on Danube river flow variability. Geophys. Res. Lett. 31, 2-5, https://doi.org/10.1029/2004GL020559

Salmi, T., Maata, A., Antilla, P., Ruoho-Airola, T., Amnell, T. (2002), Detecting trends of annual values of atmospheric pollutants by the Mann-Kendall test and 
Sen's slope estimates - the Excel template application Makesens. Finnish Meteorological Institute, Helsinki, Finland, $35 \mathrm{pp}$.

Sen, P.K. (1968), Estimates of the regression coefficient based on Kendall's tau. J. Am.

Stat. Assoc. 63, 1379-1389, 10.1080/01621459.1968.10480934

Stahl, K., Hisdal, H., Hannaford, J., Tallaksen, L.M., van Lanen, H.A.J., Sauquet, E., Demuth, S., Fendekova, M., Jódar, J. (2010), Streamflow trends in Europe: evidence from a dataset of near-natural catchments. Hydrol. Earth. Syst. Sci. 14, 2367-2382, 10.5194/hess-14-2367-2010

Stahl, K., Tallaksen, L.M., Hannaford, J., van Lanen, H.A.J. (2012) Filling the white space on maps of European runoff trends: estimates from a multi-model ensemble. Hydrol. Earth. Syst. Sci. 16, 2035-2047, https://doi.org/10.5194/hess-16-2035-2012

Șen, Z. (2012), Innovative trend analysis methodology. J. Hydrol. Eng. 17, 1042-1046, https://doi.org/10.1061/(ASCE)HE.1943-5584.0000556

Şen, Z. (2017), Innovative trend significance test and applications. Theor. Appl. Climatol. 127, 939-947, https://doi.org/10.1007/s00704-015-1681-x

Vorosmarty, C.J., Green, P., Salisbury, J., Lammers R.B. (2000), Global water resources: vulnerability from climate change and population growth. Science 289, 284-288, https://doi.org/10.1126/science.289.5477.284

Walling, D.E. (2008), The changing sediment loads of the world's rivers. IAHS Publication 325, 323-338, [link]

Walling, D.E., Fang, D. (2003), Recent trends in the suspended sediment loads of the world's rivers. Global Planet. Change 39, 111-126, https://doi.org/10.1016/S09218181(03)00020-1

Zhao, G., Mu, X., Strehmel, A., Tian, P. (2014), Temporal variation of streamflow, sediment load and their relationship in the Yellow River Basin, China. PLoSONE 9(3), e91048, https://doi.org/10.1371/journal.pone.0091048

(C) 2020 by the authors. Licensee UAIC, Iasi, Romania. This article is an open access article distributed under the terms and conditions of the Creative Commons Attribution (CC BY-NC-ND) license (https://creativecommons.org/licenses/by-nc-nd/4.0). 